\title{
Inhibition of Collagen Deposition in the Extracellular Matrix Prevents the Establishment of a Stroma Supportive of Hematopoiesis in Long-term Murine Bone Marrow Cultures
}

\author{
Kenneth S. Zuckerman, R. Kent Rhodes, Danon D. Goodrum, Vina R. Patel, Betty Sparks, \\ Jackie Wells, Max S. Wicha, and Laura A. Mayo \\ Comprehensive Cancer Center and Departments of Medicinc and Biochemistry. University of Alabama in Birmingham, Birmingham, \\ Alabama 35294; and Simpson Memorial Institute and Department of Internal Medicine, \\ University of Michigan, Ann Arbor, Michigan 48109
}

\begin{abstract}
Long-term production of murine hematopoietic cells in vitro is dependent on establishment of a complex microenvironment consisting of a variety of stromal cells and an extensive extracellular matrix which includes collagen, fibronectin, laminin, proteoglycans, and other undefined components adherent to the culture dishes. Cis-4-hydroxyproline (CHP), a relatively specific inhibitor of collagen secretion, was used to examine the role of extracellular collagen deposition in supporting

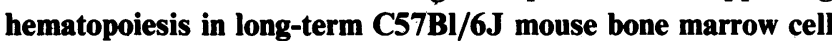
cultures. Throughout the 10 -wk culture period, all culture dishes contained either $0,10,25$, or $50 \mu \mathrm{g} / \mathrm{ml}$ of CHP. All medium and nonadherent cells were removed at weekly intervals and replaced with fresh medium containing the previous concentrations of CHP. Nonadherent cells were assayed weekly for total cells and pluripotent, erythroid, megakaryocytic, and granulocytic-macrophage progenitor cells. Dishes were killed at selected intervals to assess protein and collagen synthesis in the adherent layer. Adherent cell numbers, as judged by microscopic examination and DNA assays, correlated inversely with CHP concentrations used and paralleled degree of collagen synthesis inhibition. The decreased hemopoietic progenitor cell production correlated closely with percent inhibition of collagen synthesis and stromal cellularity. The CHP concentrations tested were not directly toxic to hemopoietic progenitor cells. These studies demonstrate that collagen deposition in the extracellular matrix of murine bone marrow cell cultures is essential to the establishment of a functional stromal microenvironment that is supportive of long-term hematopoiesis.
\end{abstract}

\section{Introduction}

The hemopoietic inductive microenvironment is thought to be necessary for the lodgement, proliferation, and differentiation of hemopoietic progenitor cells in vivo $(1,2)$. The long-term murine bone marrow cell culture system, which in many ways appears to parallel hemopoiesis in vivo, is a useful and convenient means of studying the role of the microenvironment in supporting hematopoiesis (3-8). Long-term hematopoiesis

Address correspondence to Dr. Zuckerman, Comprehensive Cancer Center.

Received for publication 11 July 1983 and in revised form 11 September 1984.

J. Clin. Invest.

(c) The American Society for Clinical Investigation, Inc. 0021-9738/85/03/970/06 \$1.00

Volume 75, March 1985, 970-975 is initiated and sustained in these cultures only after the establishment on the surface of the culture vessel of an adherent stromal cell layer consisting of macrophages, endothelial cells, adventitial reticular cells, fibroblasts, adipocytes, and perhaps other unidentified cells (3-8), as well as an extracellular matrix (ECM) ${ }^{1}$ consisting of collagen, fibronectin, laminin, proteoglycans, and probably other unidentified components $(8-12)$. The purpose of this report is to define the role of extracellular collagen in the maintenance of long-term hematopoiesis in vitro. The synthetic proline analogue cis-4hydroxyproline (CHP), which selectively inhibits collagen secretion into the ECM by stromal cells (13-16), was added to long-term murine bone marrow cultures, and its effects on collagen synthesis, stromal cells and hemopoietic progenitor cell production were determined. We demonstrated that CHP selectively inhibited collagen production and that the degree of inhibition of collagen synthesis correlated closely with the decreased proliferation of stromal cells and hemopoietic progenitor cells in these cultures.

\section{Methods}

Long-term murine bone marrow cell cultures. We used a modification of previously described techniques $(3,8)$ for establishment and maintenance of long-term murine hemopoietic cell cultures. C57B1/6J mouse (Jackșon Laboratories, Bar Harbor, ME) bone marrow cells were dispersed into a single cell suspension and seeded into $60-\mathrm{mm}$ tissue culture dishes at a concentration of $16 \times 10^{6}$ cells $/ 5 \mathrm{ml}$ of supplemented, modified Iscove's medium (Gibco Laboratories, Grand Island, NY). This medium, which was proline and lysine-free, was supplemented with $10 \%$ horse serum (Sterile Systems, Inc., Logan, UT), 10\% fetal bovine serum (Sterile Systems, Inc.), $2 \mathrm{mM}$ L-glutamine (Gibco Laboratories), $1 \mu \mathrm{M}$ hydrocortisone-21-sodium succinate (Sigma Chemical Co., St. Louis, MO), $50 \mathrm{U} / \mathrm{ml}$ penicillin, and $50 \mu \mathrm{g} / \mathrm{ml}$ streptomycin (Gibco Laboratories). Selected groups of culture dishes contained CHP (Calbiochem Behring Corp., San Diego, CA, or Sigma Chemical Co.) 10,25 , or $50 \mu \mathrm{g} / \mathrm{ml}$, and control cultures contained no CHP. The same concentration of CHP was maintained in a given culture dish throughout the entire culture period. In some cases, we permitted the cultures to grow for 3-4 wk before adding $25 \mu \mathrm{g} / \mathrm{ml} \mathrm{of}$ CHP for the remainder of the time that the cultures were maintained. Cultures were maintained at $33^{\circ} \mathrm{C}$ in a humidified atmosphere with $5 \% \mathrm{CO}_{2}$ in air. At weekly intervals, all of the medium and the nonadherent cells were harvested and the cultures were replenished with fresh medium containing the same concentration of CHP each

1. Abbreviations used in this paper: BFU-E, burst-forming units erythroid; CHP, cis-4-hydroxyproline; ECM, extracellular matrix; CFUGM, granulocyte-macrophage colony-forming units; CFU-M, megakaryocyte CFU; CFU-GEMM, mixed (pluripotent) CFU; PWM-SCM, pokeweed mitogen simulated spleen cell conditioned medium. 
Table I. Effect of Cis-4-Hydroxyproline on Collagen and Noncollagen Protein Synthesis in the Adherent Stromal Layer of Long-Term Murine Bone Marrow Cultures

\begin{tabular}{ccc}
\hline & \multicolumn{2}{c}{ \% of control protein synthesis } \\
\cline { 2 - 3 } CHP concentration & Collagen & Noncollagen protein \\
\hline $0 \mu \mathrm{g} / \mathrm{ml}$ & $100 \pm 21$ & $100 \pm 2$ \\
$10 \mu \mathrm{g} / \mathrm{ml}$ & $71 \pm 12$ & $110 \pm 6$ \\
$25 \mu \mathrm{g} / \mathrm{ml}$ & $49 \pm 7$ & $108 \pm 7$ \\
$50 \mu \mathrm{g} / \mathrm{ml}$ & $25 \pm 13$ & $75 \pm 5$ \\
\hline
\end{tabular}

week. Nonadherent cells were counted using a Coulter model Zf particle counter. Cell viability was assessed by trypan blue dye exclusion.

Hematopoietic progenitor cell assays. Primitive erythroid progenitor cells (BFU-E), granulocyte-macrophage progenitors (CFU-GM), megakaryocyte progenitors (CFU-M), and probable pluripotent hematopoietic progenitors (CFU-GEMM) were assayed in 0.3-ml plasma clot cultures, as described previously (8). All cultures contained Iscove's medium (Gibco Laboratories), 20\% fetal bovine serum (Sterile Systems, Inc.), $1 \%$ deionized bovine serum albumin (Sigma Chemical Co.), 10\% citrated bovine plasma (Irvine Scientific Co., Irvine, CA), $1 \mathrm{U} / \mathrm{ml}$ bovine thrombin (Sigma Chemical Co.), and $10^{5}$ fresh marrow cells or nonadherent cells from long-term bone marrow cultures per $0.5-\mathrm{ml}$ well. The plasma clot cultures were maintained at $37^{\circ} \mathrm{C}$ in a humidified incubator with $5 \% \mathrm{CO}_{2}$ in air. BFU-E were cultured for 8-10 d in the presence of $3 \mathrm{U} / \mathrm{ml}$ erythropoietin (human urinary erythropoietin, lot CAT-1, kindly provided by the National Heart, Lung and Blood Institute). Clots were stained with benzidine- $\mathrm{H}_{2} \mathrm{O}_{2}$ and hematoxylin, and colonies of $>64$ cells or $>2$ subcolonies were counted. CFU-GM were cultured for $7 \mathrm{~d}$ in the presence of $10 \%$ pokeweed mitogen stimulated spleen cell conditioned medium (PWM-SCM). Clots were stained with hematoxylin, and colonies of $>40$ granulocytes and/or macrophages were counted. CFU-M were cultured for $7 \mathrm{~d}$ in the presence of $10 \%$ PWM-SCM, and colonies of at least three acetylcholinesterase-staining cells were counted. CFU-GEMM were cultured in the presence of $10 \%$ PWM-SCM and $3 \mathrm{U} / \mathrm{ml}$ erythropoietin. Cultures were stained with benzidine- $\mathrm{H}_{2} \mathrm{O}_{2}$ and hematoxylin, and colonies of $>100$ cells containing erythroid cells, megakaryocytes, and granulocytes and/or macrophages were counted.

Assays for collagen and noncollagen protein synthesis. After 3-4 wk of culture, $\left[{ }^{3} \mathrm{H}\right]$ lysine $(74.4 \mathrm{Ci} / \mathrm{mmol})$ (New England Nuclear, Boston, MA) $(5 \mu \mathrm{Ci} / \mathrm{ml})$, ascorbic acid $(50 \mu \mathrm{g} / \mathrm{ml})$, and $\beta$-aminopropionitrile $(50 \mu \mathrm{g} / \mathrm{ml})$ were added to selected culture dishes and the dishes were incubated for an additional $2 \mathrm{~d}$. The medium was washed from the dishes and the culture dishes with an intact adherent stromal layer were stored at $-80^{\circ} \mathrm{C}$ until they could be assayed.

Total protein and collagen synthesis were assayed as described by Peterkofsky and Diegelman (17). Briefly, total proteins in the samples were precipitated by $10 \%$ trichloroacetic acid and tannic acid. Total protein synthesis was determined by scintillation counting, and collagen synthesis was determined after digestion of the protein with purified protease-free bacterial collagenase (Advanced Biofractures, Lynbrook, NY). DNA in the stromal layer was assayed fluorometrically using the technique of Setaro and Morley (18).
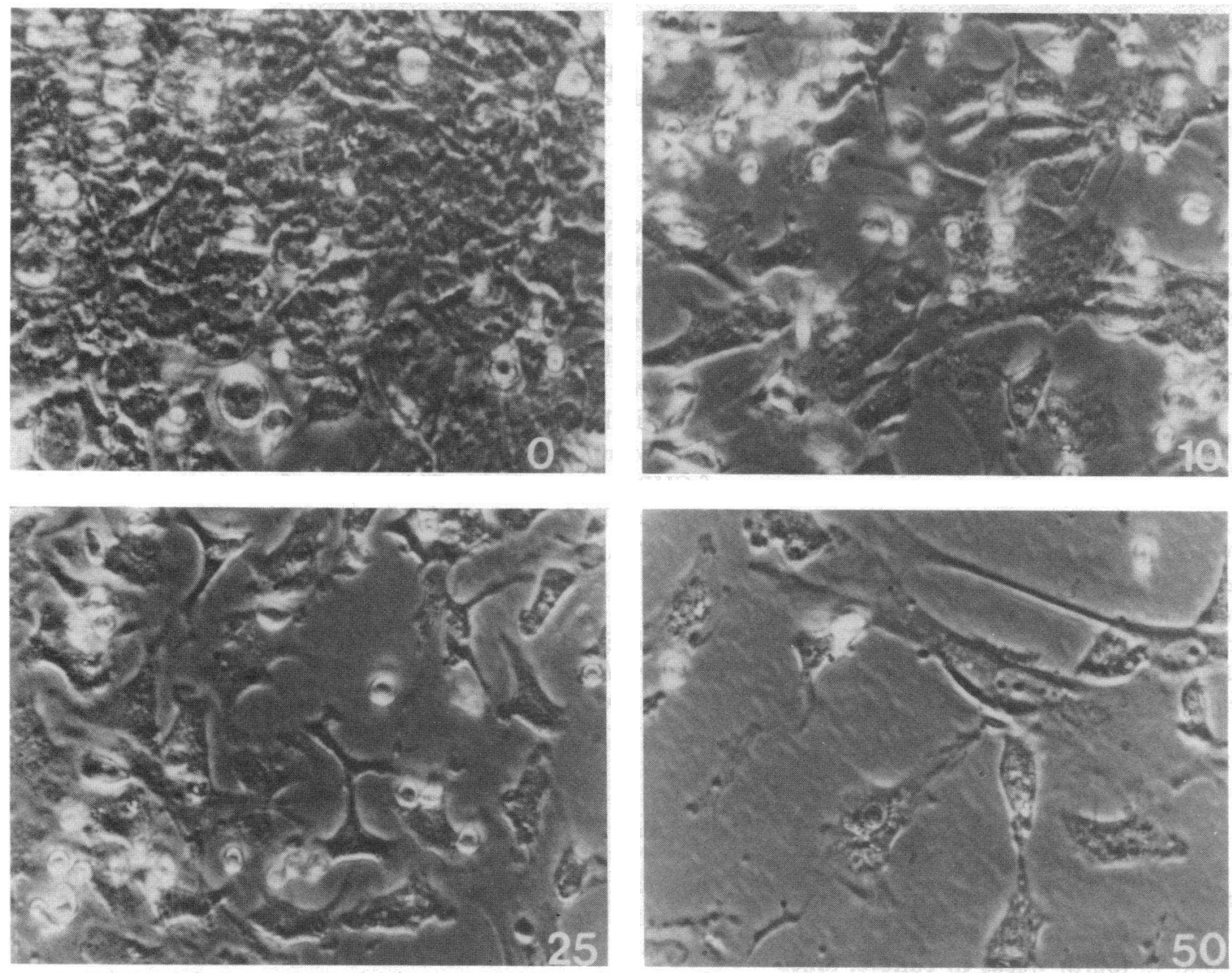

Figure 1. Effect of CHP on adherent stroma formation in long-term murine bone marrow cultures $(10 \mathrm{~d})$. The four panels are photomicrographs $(\times 320)$ of representative areas of the adherent cell layer of cultures exposed continuously to $0,10,25$, or $50 \mu \mathrm{g}$ of $\mathrm{CHP} / \mathrm{ml}$, as indicated on the individual panels. 

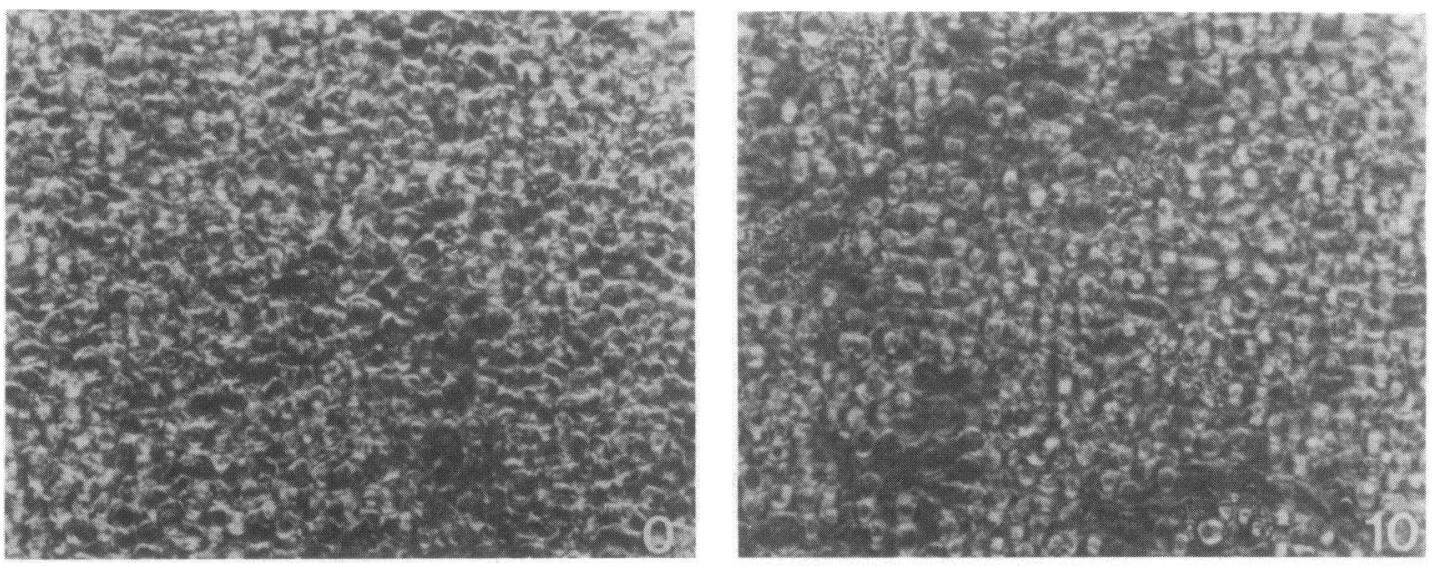

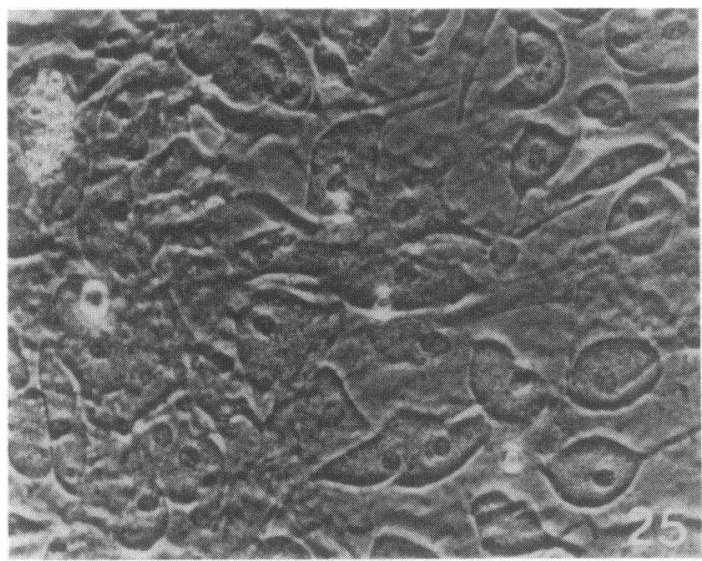

Figure 2. Effect of CHP on adherent stroma formation in long-term murine bone marrow cultures ( $5 \mathrm{wk})$. The four panels are photomicrographs $(\times 320)$ of representative areas of the adherent cell layer of

Stromal cell adherence assays. Long-term marrow cultures were maintained for $\sim 4 \mathrm{wk}$, at which time there was a confluent adherent stromal cell layer. The dishes were washed with sterile medium to remove nonadherent cells. Next the culture dishes were washed with phosphate-buffered saline without $\mathrm{Ca}^{++}$or $\mathrm{Mg}^{++}$. Next, trypsin $0.5 \%$ / EDTA $0.2 \%$ (Gibco Laboratories) was added and the dishes were incubated at $37^{\circ} \mathrm{C}$, and agitated gently at 1-min intervals until the adherent cells floated into the medium ( 5-6 min). The cells were washed and pipetted gently to achieve a single cell suspension and were diluted in modified Iscove's medium (as described above, including $20 \%$ serum and antibiotics) to a final concentration of $2 \times 10^{4}$ cells/ $\mathrm{ml}$. $5 \mathrm{ml}$ containing $10^{5}$ cells ( $>99 \%$ viable by trypan blue dye exclusion) was added to each $60-\mathrm{mm}$ culture dish with $2-\mathrm{mm}$ square grids. CHP in a final concentration of 25 or $50 \mu \mathrm{g} / \mathrm{ml}$ was added to selected aliquots of the cell suspension. After $24 \mathrm{~h}$, these secondary culture dishes were washed vigorously with fresh medium. The adherent cells were stained with hematoxylin, and the adherent cells in at least 10 squares from all areas of each dish were counted. The number of adherent cells per dish $( \pm$ SEM) was calculated.

\section{Results}

Inhibition of collagen synthesis by $C H P$. In preliminary studies (unpublished data) we noted a burst in collagen deposition by stromal cells in the second to fourth weeks in culture. Since the selective inhibitory effect of CHP on collagen synthesis in the stromal layer was similar at each time point tested, the effect of CHP on collagen and noncollagen protein synthesis at three weeks is shown in Table I. There was a direct correlation between CHP concentration and degree of inhibition of collagen synthesis. There was no detectable inhibition of noncollagen protein synthesis at 10 or $25 \mu \mathrm{g} \mathrm{CHP} / \mathrm{ml}$, but modest inhibition at $50 \mu \mathrm{g} / \mathrm{ml}$.

Effect of CHP on the hemopoietic stroma in vitro. As shown in Figs. 1 and 2, the stromal cellularity after both $10 \mathrm{~d}$ and $5 \mathrm{wk}$ of culture correlated inversely with the concentration of $\mathrm{CHP}$ in the cultures. This was confirmed quantitatively by assays of DNA content in the stromal cell layer (Table II). The DNA levels reflected cellularity of the adherent layers,

Table II. Effect of Cis-4-Hydroxyproline on Stromal and Hemopoietic Cellularity in Long-Term Murine Bone Marrow Cultures

\begin{tabular}{llll}
\hline & $\begin{array}{l}\text { Collagen } \\
\text { synthesis/dish } \\
\text { (\% of control) }\end{array}$ & $\begin{array}{l}\text { Adherent } \\
\text { stromal } \\
\text { cellularity } \\
\text { ( } \mu \mathrm{g} \text { DNA dish) }\end{array}$ & $\begin{array}{l}\text { Total hemopoietic cell } \\
\text { production/10 wk }\end{array}$ \\
\hline $0 \mu \mathrm{g} / \mathrm{ml}$ & $100 \pm 21$ & $81.5(100 \%)^{*}$ & $26.5 \times 10^{6}(100 \%)^{*}$ \\
$10 \mu \mathrm{g} / \mathrm{ml}$ & $71 \pm 12$ & $62.0(76 \%)$ & $23.7 \times 10^{6}(89 \%)$ \\
$25 \mu \mathrm{g} / \mathrm{ml}$ & $49 \pm 7$ & $41.4(51 \%)$ & $14.2 \times 10^{6}(54 \%)$ \\
$50 \mu \mathrm{g} / \mathrm{ml}$ & $25 \pm 13$ & $22.2(27 \%)$ & $3.6 \times 10^{6}(14 \%)$
\end{tabular}

* Number in parenthesis is percent of control value. 
Table III. Effect of Cis-4-Hydroxyproline on Adherence of Cultured Murine Bone Marrow Stromal Cells to Tissue Culture Dishes

\begin{tabular}{cl}
\hline CHP concentration & Adherent stromal cells per dish \\
\hline $0 \mu \mathrm{g} / \mathrm{ml}$ & $31,137 \pm 3,839$ \\
$25 \mu \mathrm{g} / \mathrm{ml}$ & $29,052 \pm 1,078$ \\
$50 \mu \mathrm{g} / \mathrm{ml}$ & $16,470 \pm 729$ \\
\end{tabular}

since $<1 \%$ of cells were binucleated. This inhibition of stromal cellularity was not caused by an inhibition of adherence of the freshly explanted marrow stromal cells to the culture dishes (Table III).

Effect of CHP on hemopoietic cell production in vitro. Increasing concentrations of CHP resulted in a progressive decrease in total hemopoietic cell production over the $10 \mathrm{wk}$ during which the cultures were maintained (Table II and Fig. 3). Also, as shown in Fig. 4, the decreased production of hemopoietic progenitor cells in cultures containing CHP was even more profound. The fact that CHP concentrations that inhibited collagen synthesis, stromal cellularity, and hemopoietic cell production by as much as $50 \%$ (i.e., $25 \mu \mathrm{g} / \mathrm{ml}$ ) did not have a direct toxic effect on hemopoietic progenitor cells was demonstrated in five ways. Direct addition of CHP $(10,25$, or $50 \mu \mathrm{g} / \mathrm{ml}$ ) to plasma clot cultures of fresh murine bone marrow cells had no inhibitory effect on CFU-GM or CFU-M (91-
$118 \%$ of control growth). BFU-E and CFU-GEMM growth were not inhibited significantly by addition of 10 or $25 \mu \mathrm{g}$ of CHP per milliliter to plasma clot cultures (92-118\% of control growth), but the $50-\mu \mathrm{g} / \mathrm{ml}$ concentration inhibited BFU-E by $15 \%$ and CFU-GEMM by $27 \%$. Second, the numbers of surviving nonadherent hemopoietic progenitor cells recoverable after 1 wk of exposure to CHP in the long-term cultures was the same or greater in cultures exposed to CHP 25 or $50 \mu \mathrm{g} /$ $\mathrm{ml}$ for that entire week as compared with cultures containing no CHP. Third, when the cultures were maintained for 3 or 4 wk without CHP, and a confluent stromal layer was permitted to form, subsequent continuous exposure of the cultures to 25 $\mu \mathrm{g} / \mathrm{ml} \mathrm{CHP} \mathrm{had} \mathrm{no} \mathrm{inhibitory} \mathrm{effect} \mathrm{on} \mathrm{hematopoiesis.} \mathrm{Fourth,}$ as shown in Table III, normal cultured adherent marrow cells that were dispersed and then placed in new culture dishes adhered normally to the secondary dishes in the presence of $25 \mu \mathrm{g} / \mathrm{ml} \mathrm{CHP}$, the CHP concentration that resulted in about a $50 \%$ decrease in collagen synthesis, stromal cellularity, and hemopoietic cell production in the long-term marrow cultures. However, there was a significant inhibition of stromal cell adherence in the presence of $50 \mu \mathrm{g}$ of $\mathrm{CHP} / \mathrm{ml}$, a concentration that was noted to cause some inhibition of noncollagen protein synthesis and some toxicity to hemopoietic progenitor cells. Finally, when sera containing high concentrations of proline were used, CHP in concentrations up to $100 \mu \mathrm{g} / \mathrm{ml}$ had minimal inhibitory effects on collagen synthesis and stromal cell growth and resulted in no decrease in the level of hemopoietic cell production; but after the serum was dialyzed,

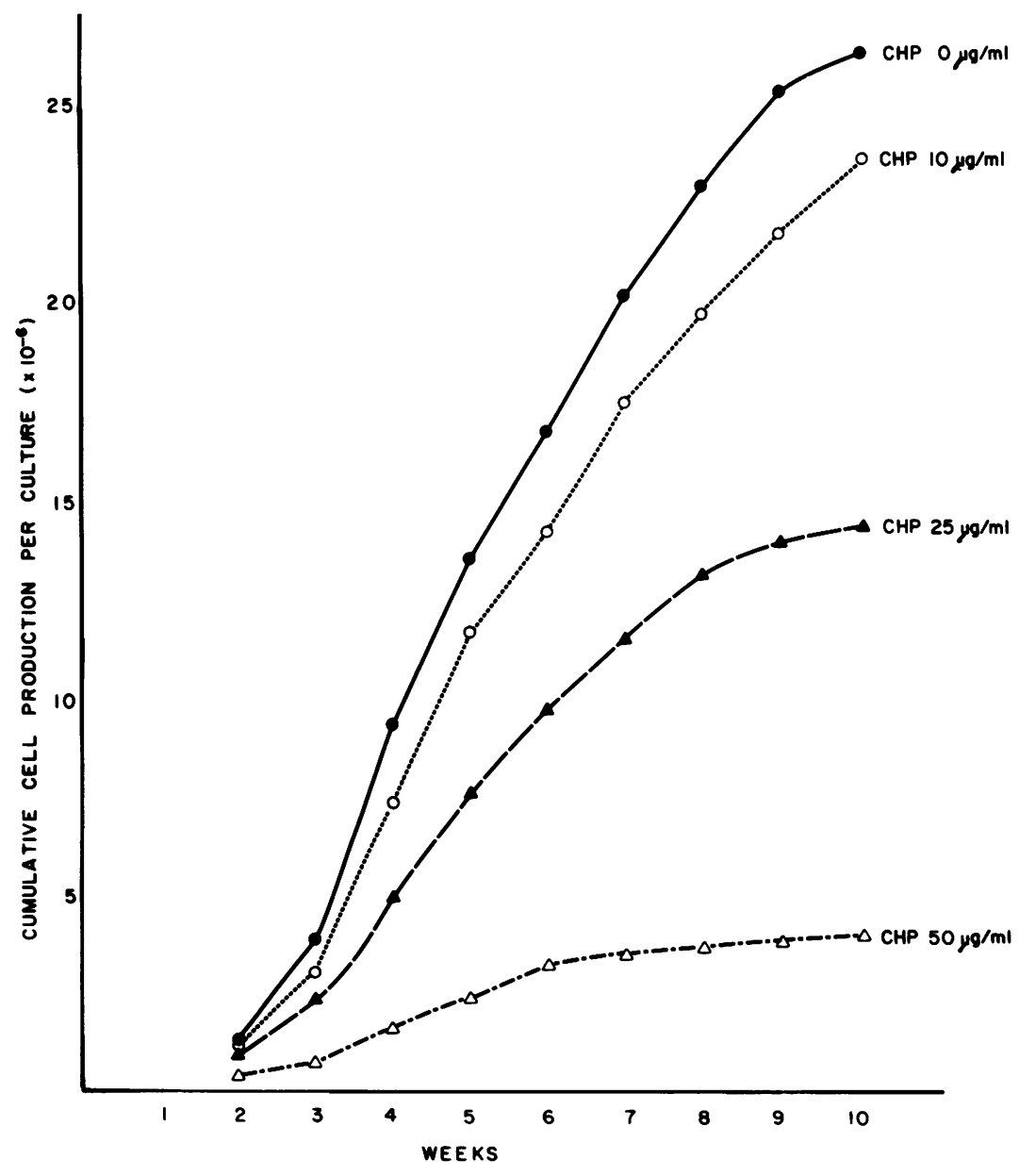

Figure 3. Effect of CHP on hematopoietic cell production in long-term murine bone marrow cell cultures. All nonadherent cells were removed from the cultures at weekly intervals and counted. Each datum point represents the mean cumulative number of hemopoietic cells recovered from the cultures (3-5 separate experiments with 3-20 culture dishes per group). 

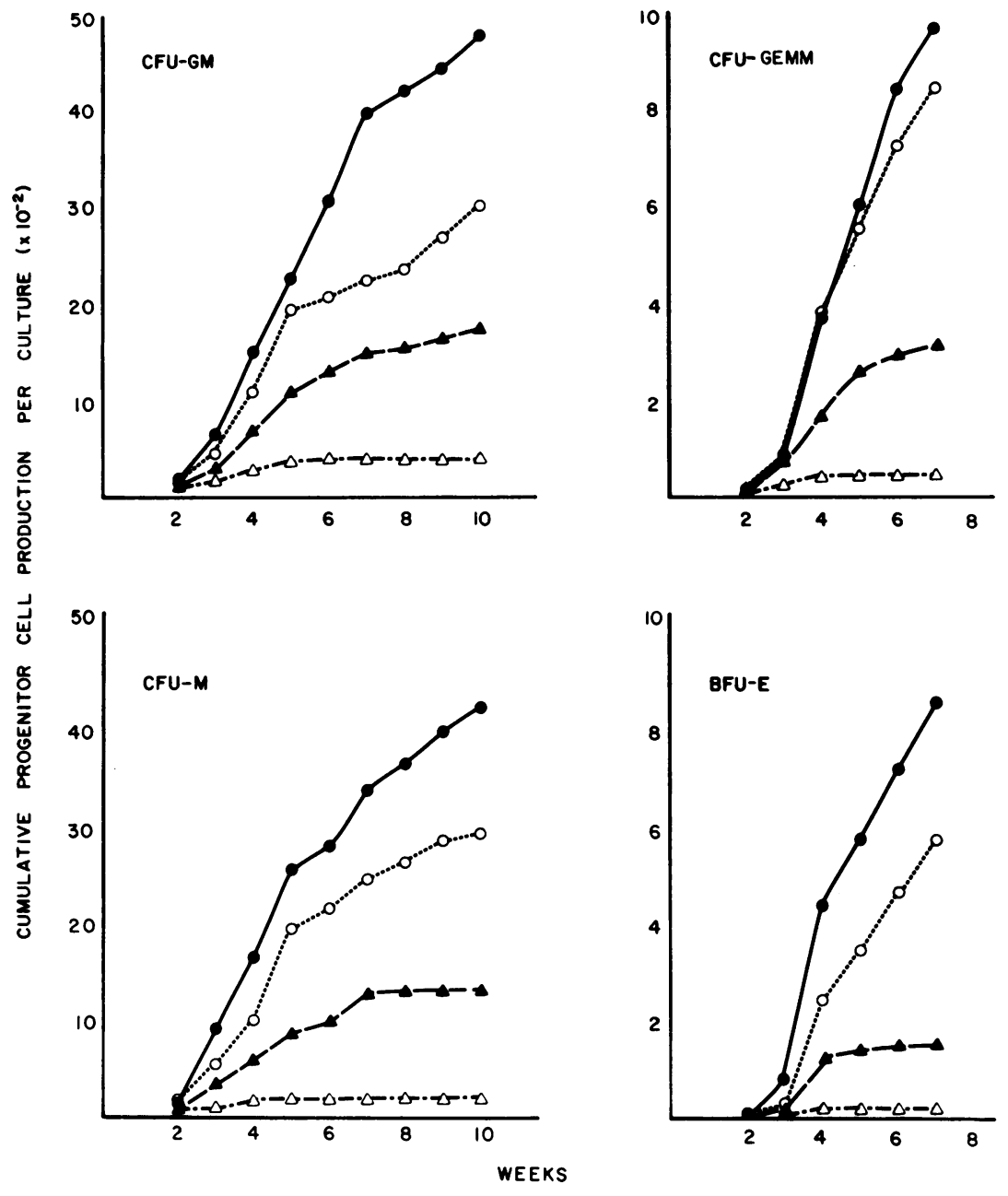

Figure 4. Effect of CHP on hematopoietic progenitor cell production in long-term murine bone marrow cell cultures. All nonadherent cells were removed weekly, counted and assayed for content of each of the hemopoietic progenitor cells listed. Each datum point represents the mean cumulative number of hematopoietic progenitor cells recovered from the cultures (3-5 separate experiments with triplicate cultures from pooled cells from 320 culture dishes per group). The symbols used in this figure are the same as those used and defined in Fig. 3. hemopoiesis was supported in the absence of CHP, and hemopoietic cell production was decreased in cultures containing 25 or $50 \mu \mathrm{g} / \mathrm{ml}$ of CHP.

\section{Discussion}

The hemopoietic microenvironment is acknowledged widely to be essential for maintenance and differentiation of hemopoietic progenitor cells in vivo $(1,2)$ and in vitro $(3-12)$. Although the cellular composition of the hemopoietic microenvironment has been studied extensively, the composition of the extracellular matrix has been defined only partially. Studies from our laboratories and others have demonstrated that the ECM in long-term bone marrow cultures contains collagen types I, III, and IV, fibronectin, laminin, and proteoglycans (8-12). In addition, there certainly are many other components of the hemopoietic ECM which have not been characterized yet.

It is clear from studies of hepatic and mammary cell culture systems that the ECM of these organs is essential for supporting and/or promoting normal differentiation and longterm viability in vitro (19-24). Furthermore, this supportive or inductive effect of the ECM is tissue specific (21-24). However, the identities of the tissue-specific components of the ECM are not known.

Very little is known about the importance of the various ECM components in permitting or promoting hematopoietic cell proliferation and differentiation in vivo or in vitro. Spooncer et al. (12) reported recently that addition of xylosides to longterm murine bone marrow cultures in order to stimulate glycosaminoglycan (especially chondroitin sulfate) synthesis resulted in an approximate three- to fivefold enhancement of hematopoietic cell production. Thus, they proposed that proteoglycans play an important role in regulating hemopoiesis.

We have shown in these studies that the proline analogue CHP inhibited the establishment of the adherent stroma and resulted in subsequent decreased production of hemopoietic progenitor cells in long-term murine bone marrow cultures. The mechanism by which CHP inhibits collagen synthesis (secretion) by cells is unique $(13,14,25)$. CHP is incorporated in place of proline into newly synthesized proteins. In the case of nearly all proteins except collagen, the presence of CHP instead of proline does not interfere with synthesis or secretion of the protein by cells. However, in collagen molecules many of the proline residues are converted to trans-hydroxyproline, which is a necessary step in the formation of a stable triple helical portion of collagen molecules (26). If a stable triple helix is not formed, the collagen that is being synthesized within a cell cannot be secreted normally; and most of these defective collagen molecules are degraded intracellularly. There are only two other proteins that have been found to have collagen-like triple helical structures, and which are subject to specific inhibition by CHP. The two proteins, acetylcholinesterase and the complement component Clq (27), play no 
known or hypothesized role in regulating hematopoiesis. The selective inhibition of collagen deposition in the presence of CHP has been demonstrated in other systems $(15,16)$ and was confirmed in long-term bone marrow cultures by measuring total protein and collagen synthesis. The percent reduction in both stromal cell and hemopoietic progenitor cell production in the presence of CHP closely paralleled the percent inhibition of collagen synthesis, and occurred at concentrations of CHP that did not affect noncollagen protein synthesis, were not directly toxic to hemopoietic progenitor cells, and did not inhibit adherence of marrow stromal cells to the culture dishes.

This study suggests that the deposition of collagen in the hematopoietic extracellular matrix is essential for the maintenance of long-term hematopoiesis in vitro. This finding is consistent with our previous observation that hemopoietic progenitor cell production in these cultures temporally followed the deposition of extracellular matrix in the adherent layer, as determined by immunofluorescence (8). It also accounts for our finding that these cultures were resistant to the inhibitory effects of CHP if an adherent extracellular matrix and stromal cell layer already had formed before exposure of the cultures to CHP. The role of collagen in hemopoietic cell proliferation and differentiation may be similar to its role in other culture systems such as mammary gland cultures, since the degree of mammary cell proliferation and differentiation is reduced in the presence of CHP in vitro (15) and in vivo (16).

Since CHP inhibits the deposition of all collagen types, the relative roles of all the collagen subtypes in supporting hemopoiesis in vitro are not clear. Furthermore, because of the widespread distribution of most collagen subtypes in many organs, it seems unlikely that collagen itself is responsible for tissue specific supportive or stimulatory effects on hematopoiesis. It is more likely that collagen forms a structural framework for the deposition of other organ specific extracellular matrix components. Stromal and hemopoietic progenitor cells lodge, interact, proliferate, and differentiation upon and within this extracellular matrix. This sequence of events appears necessary to support long-term hematopoiesis. The identification of organ specific components of the extracellular matrix that modulate hemopoiesis awaits further investigation.

\section{Acknowledgments}

This work was supported by grants AM 31248 and AM 33498 from the U. S. Public Health Service.

\section{References}

1. Wolf, N. 1979. The haemopoietic microenvironment. Clin. Haematol. 8:469-500.

2. Tavassoli, M. 1975. Studies on hemopoietic microenvironments. Exp. Hematol. 3:213-226.

3. Dexter, T. M., and N. G. Testa. 1976. Differentiation and proliferation of hemopoietic cells in culture. Methods Cell. Biol. 14: 387-405.

4. Allen, T. D. 1981. Haemopoietic microenvironments in vitro: ultrastructural aspect. In Ciba Foundation Symposium 84, Microenvironments in Haemopoietic and Lymphoid Differentiation. Pitman Books Ltd., London. 38-67.

5. Dexter, T. M., T. D. Allen, and L. G. Lajtha. 1977. Conditions controlling the proliferation of haemopoietic stem cells in vitro. $J$. Cell. Physiol. 91:335-344.
6. Tavassoli, M., and K. Takahashi. 1982. Morphological studies on long-term culture of marrow cells: characterization of the adherent stromal cells and their interactions in maintaining the proliferation of hemopoietic stem cells. Am. J. Anat. 164:91-111.

7. Dexter, T. M., N. G. Testa, T. D. Allen, T. Rutherford, and E. Scolnick. 1981. Molecular and cell biologic aspects of erythropoiesis in long-term bone marrow cultures. Blood. 58:699-707.

8. Zuckerman, K. S., and M. S. Wicha. 1983. Extracellular matrix production by the adherent cells of long-term murine bone marrow cultures. Blood. 61:540-547.

9. Bentley, S. A., and J.-M. Foidart. 1980. Some properties of marrow derived adherent cells in tissue culture. Blood. 56:1006-1012.

10. Bentley, S. A. 1982. Collagen synthesis by bone marrow stromal cells: a quantitative study. Br. J. Haematol. 50:491-497.

11. Castro-Malaspina, H., R. E. Gay, S. Saleton, B. Oettgen, S. Gay, and M. A. S. Moore. 1981. Phenotypic characterization of the adherent cell layer in long-term mouse bone marrow cultures. Blood. 58(Suppl. 1):107a. (Abstr.)

12. Spooncer, E., J. T. Gallagher, F. Krizsa, and T. M. Dexter. 1983. Regulation of haemopoiesis in long-term bone marrow cultures. IV. Glycosaminoglycan synthesis and the stimulation of haemopoiesis by $\beta$-D-xylosides. J. Cell. Biol. 96:510-514.

13. Vitto, J., and D. Prockop. 1977. Incorporation of proline analogues into procollagen. Arch. Biochem. Biophys. 181:293-299.

14. Vitto, J., and D. Prockop. 1974. Effects of proline analogues on collagen synthesis. Biochim. Biophys. Acta. 336:235-251.

15. Wicha, M. S., L. A. Liotta, S. Garbisa, and W. R. Kidwell. 1979. Basement membrane collagen requirements for attachment and growth of mammary epithelium. Exp. Cell Res. 124:181-190.

16. Wicha, M. S., L. A. Liotta, B. K. Vonderhaar, and W. R. Kidwell. 1980. Effects of inhibition of basement membrane collagen deposition on rat mammary development. Dev. Biol. 80:253-266.

17. Peterkofsy, D., and R. Diegelman. 1971. Use of a mixture of protease-free collagenase for a specific assay of radioactive collagen in the present of other proteins. Biochemistry. 10:988-994.

18. Setaro, F., and C. G. D. Morley. 1976. A modified fluorometric method for the determination of microgram quantities of DNA from cell or tissue cultures. Anal. Biochem. 71:313-317.

19. Reid, L. M., and M. Rojkind. 1979. New techniques for culturing differentiated cells: reconstituted basement membrane rafts. Methods Enzymol. 58:263-278.

20. Reid, L. M., Z. Gaitmaitan, I. Arias, P. Ponce, and M. Rojkind. 1980. Long-term cultures of normal rat hepatocytes on liver biomatrix. Ann. NY Acad. Sci. 349:70-76.

21. Rojkind, M., Z. Gaitmaitan, S. Mackenson, M. A. Giambrone, P. Ponce, and L. M. Reid. 1980. Connective tissue biomatrix: its isolation and utilization for long-term cultures of normal rat hepatocytes. J. Cell. Biol. 87:255-263.

22. Ponce, P., J. Cordero, and M. Rojkind. 1981. A non-collagenous matrix for attachment of rat hepatocytes in culture. Hepatology. 1: 204-210.

23. Wicha, M. S., G. Lowrie, E. Kohn, P. Bagavandoss, and T. Mahn. 1982. Extracellular matrix promotes mammary epithelial growth and differentiation in vitro. Proc. Natl. Acad. Sci. USA. 79:3213-3217.

24. Wicha, M. S. 1982. Growth and differentiation of rat mammary epithelium on mammary gland extracellular matrix. In Extracellular Matrix. S. Hawkes and J. Wang, editors. Academic Press, Inc., New York. 309-314.

25. Chvapil, M. 1982. Experimental modifications of collagen synthesis and degradation and their therapeutic applications. In Collagen in Health and Disease. J. B. Weiss and M. I. V. Jayson, editors. Churchill Livingstone, London. 206-217.

26. Kivirikko, K. I., and R. Myllylä. 1982. Post-translational modifications. In Collagen in Health and Disease. J. B. Weiss and M. I. V. Jayson, editors. Churchill Livingstone, London. 101-120.

27. Reid, K. B. M. 1982. Proteins containing collagen sequences. In Collagen in Health and Disease. J. B. Weiss and M. I. V. Jayson, editors. Churchill Livingstone, London. 18-27. 